UDC 330.15:005.932(477)

JEL: O13, Q30, R40

\author{
Alina Kodzhebash \\ Institute of Market Problems and \\ Economic \& Ecological Research of \\ the NAS of Ukraine, \\ Odessa, Ukraine \\ E-mail: alinakod130@gmail.com \\ orcid.org/0000-0002-8161-632X
}

Received: January， 2019

Accepted: February, 2019

DOI:10.31520/2616-7107/2019.3.1-7

C Economics. Ecology. Socium, 2019

CC BY-NC 4.0 license

\section{PROBLEMS OF REGULATION OF TRANSPORT AND LOGISTICS PROCESSES OF RESPONSIBLE WASTE MANAGEMENT IN UKRAINE}

Introduction. Control of waste management is a complex process that involves organizational-economic and economicenvironmental components that are directly or indirectly related to the production and consumption of products, supply of raw materials, natural resources, related information and financial flows, etc. Transport and logistics occupy a special place among them, because of the specifics of waste as an object of management, as well as related issues of environmental pollution and the impact on the health of the population. Transport-logistics approaches are needed to allow the use of appropriate management levers and instruments aimed at solving a complex issue when production and associated material flows are considered in close connection with the movement of waste generated during production and consumption.

Aim and tasks. The purpose of the article is to substantiate the conceptual approach to the management of transport-logistics processes in the field of responsible waste management on the basis of analysis of economic-ecological and organizational issues, and prospects of its development in Ukraine.

Results. As a result of the research, it has been determined that reversible logistics is a means of achieving positive ecologicaleconomic efficiency, the feasibility of which, first and foremost, of the transport component is confirmed by the fact that in the long run, Ukraine can significantly reduce the level of environmental pollution caused by the formation and placement of waste, but the volume of emissions in the transport sector will increase. Accordingly, it is necessary to increase the role of goal-setting functions and coordination of actions in the field of waste management; the main goal at the same time is to increase the ecological-economic efficiency of processes associated with transportation, as well as sorting, storage and disposal of household and industrial waste. This principle is the basis for integrating transport-logistics operations into a waste management system, the main elements of which are management functions and associated environmental-economic instruments for influencing waste management processes. The subsystem of ecological management within the framework of the waste management system, in particular, its transport-logistic component, which forms the ecological policy at micro and macro levels, deserves special attention; and is an effective instrument for implementing the concept of motivated liability.

Conclusions. In the field of waste management, one of the top priorities is the task of increasing the role of transport logistics. Solving the problem of managing transport-logistics processes of responsible waste management is seen in two aspects: integration of the transportlogistics system into the waste management system at the territorial level; creating an economic space for mutually agreed solutions to issues of transportation and other logistics waste operations. This conceptual approach will create competitive conditions for the subjects of environmental-economic activities, which initiate the responsible management of waste in aspects of their transportation, sorting, utilization, etc. in accordance with ISO standards in the areas of waste and transport management and the environmental management system.

Keywords: waste management, transport logistics, ecological management, responsibility. 
УДК 330.15:005.932(477)

JEL: O13, Q30, R40

\section{Аліна Коджебаш}

Інститут проблем ринку та економіко-екологічних досліджень НАНУ, м. Одеса, Україна E-mail: alinakod130@gmail.com orcid.org/0000-0002-8161-632X

Отримано: Січень, 2019

Прийнято: Лютий, 2019

DOI:10.31520/2616-7107/2019.3.1-7

(C) Економіка. Екологія. Соціум, 2019 CC BY-NC 4.0 ліцензія

\section{ПРОБЛЕМИ УПРАВЛІННЯ ТРАНСПОРТНО- ЛОГІСТИЧНИМИ ПРОЦЕСАМИ ВІДПОВІДАЛЬНОГО ПОВОДЖЕННЯ 3 ВІДХОДАМИ В УКРАЇНІ}

Вступ. Управління в сфері поводження 3 відходами $€$ складним процесом, який включає в себе організаційноекономічні та економіко-екологічні складові, що прямо чи опосередковано стосуються виробництва та споживання продукції, постачання сировини, видобутку природних ресурсів, пов'язаних із цим інформаційних і фінансових потоків тощо. Транспорт і логістика посідають серед них особливе місце, що пояснюється специфікою відходів як об'єкта управління, а також пов'язаних із ним питань забруднення довкілля та впливу на здоров'я населення.

Мета і завдання. Мета статті полягає в обгрунтуванні концептуального підходу до управління транспортнологістичними процесами в сфері відповідального поводження 3 відходами на основі аналізу економіко-екологічних i організаційних питань і перспектив ії розвитку в Україні.

Результати. Як результат дослідження визначено, що реверсивна логістика $\epsilon$ засобом досягнення позитивної екологоекономічної ефективності, доцільність розвитку якого, передусім, транспортної складової підтверджується тим, що за оптимістичним сценарієм Україна в довгостроковій перспективі може значно знизити рівень забруднення довкілля, спричинене утворенням і розміщенням відходів, але при цьому зростуть обсяги викидів у сфері транспорту. Відповідно, слід підвищити роль функції цілепокладання та координаційних дій в галузі поводження 3 відходами із підвищенням еколого-економічної ефективності процесів, пов'язаних із транспортуванням, а також сортуванням, складуванням та утилізацією побутових i промислових відходів. Цей принцип є підгрунтям інтегрування транспортно-логістичних операцій у систему управління відходами, основними елементами якої є функції управління та пов'язані 3 ними еколого-економічні інструменти впливу на процеси поводження 3 відходами. Досліджено підсистема екологічного менеджменту в рамках системи управління відходами, зокрема, іiі транспортно-логістична складова, що, формує екологічну політику на мікро- та макрорівнях; та $є$ дієвим інструментом реалізації концепції мотивованої відповідальності.

Висновки. В сфері поводження 3 відходами одним iз першочергових $\epsilon$ завдання підвищення ролі транспортної логістики. Вирішення проблеми управління транспортнологістичними процесами відповідального поводження 3 відходами вбачається в двох аспектах: інтегрування транспортно-логістичної системи в систему управління відходами на територіальному рівні; створення економічного простору для взаємоузгодженого вирішення питань щодо транспортування та інших логістичних операцій з відходами. Такий концептуальний підхід дозволить створити конкурентні умови для суб'єктів еколого-економічної діяльності, що ініціюють відповідальне поводження з відходами в аспектах їх транспортування, сортування, утилізації тощо згідно зі стандартами ISO в сферах поводження 3 відходами та транспорту і щодо системи екологічного менеджменту.

Ключові слова: управління відходами, транспортна логістика, екологічний менеджмент, відповідальність. 
Introduction. Regulation of waste management is a complex process that involves organizational-economic and economicenvironmental components that are directly or indirectly related to the production and consumption of products, supply of raw materials, natural resources, related information and financial flows, etc. Transport and logistics occupy a special place. This is due to the specific nature of the waste as an object of management, as well as the related issues of environmental pollution and the impact on the health of the population, as well as the problem of losses to the national economy. The level of potential environmental and economic losses depends on how far the waste is exported in a timely manner, particularly hazardous waste, how it gets to the places of storage and processing, etc. This question is much more complicated than simply transportation of the waste: we need logistic, in particular, transport-logistic approaches in order to gradually move to low-cost technologies and business processes. Such approaches allow the use of appropriate management levers and instruments aimed at solving a complex issue when production and associated material flows are considered inextricably linked, including with the movement of waste generated in the process of production and consumption. Therefore, research of the issues related to improving the management of transport-logistics processes in the field of waste management is currently relevant.

Analysis recent research and publications. In the article we can find the analysis of researches about the ecologicaleconomic issues that arise in the field of waste management and transport-logistics, as well as environmental management. The analysis of researches [1-6] suggests that: the need for institutionalization in the field of nature use, the resolution of environmental and economic problems by administrative methods, in particular, in the context of creating optimal mechanisms for resource allocation, as well as ecologization of innovative strategies for reducing the output of production and regulating the risks of environmental pollution to the health and welfare of the population due to the disposal of waste in the natural environment. The trends of ecological logistics and recycling of transport were considered in the researches of such Ukrainian authors as S.V. Boychenko, K. Leida, O. Ivanchenko [7], R. Voronina [8]; V. I. Vostryakova [9], L. M. Hurch and L.E Khmara [10], O. V. Dzyad, K. V. Tsvetaeva [11], V. V. Zayets [12], N. P. Popovich, M.S Malovanov, V. V. Popovich [13] - "green" logistics in Ukraine and, in particular, in its agrarian sector, advanced foreign experience of waste processing, specificity of handling of hazardous waste, etc. In the researches of authors such as X. Bing, J. M. BloemhofRuwaard, J. G. A. J. van der Vorst [14], S. Das, B. K. Bhattacharyya [15], E. E. A. Jalil, D. B. Grant, J. D. Nicholson, P. Deutz [16], R. Joshi, S. Ahmed [17], D. Khan, S.R Samadder [18], H. Marczak [19], G. Peri, P. Ferrante, M. La Gennusa, C. Pianello, G. Rizzo [20] - respectively: the issue of the sustainability of reversible logistics (on the example of plastic waste); optimization of routes of collection and transportation of solid household waste; possibility of symbiosis of reversing logistics and existing waste recycling systems; features and difficulties of collecting and transporting municipal waste in overpopulated countries such as India; waste logistics in health care institutions; the role of transportation of waste in solving the problem of reducing the ecological footprint, etc.

At the same time, the problems of managing transport-logistics processes of waste management based on the concepts of responsibility, in our opinion, require further development. Further researches of the possibilities of motivated responsibilities in the field of transport and logistics regarding its application in the waste management system are also particularly important.

Aim and tasks. The purpose of the article is to substantiate the conceptual approach to the management of transport-logistics processes in the field of responsible waste management on the basis of analysis of economic-ecological and organizational issues, and prospects of its development in Ukraine.

Results. Status and development of waste management in Ukraine, unfortunately, has had few promising prospects, as evidenced by data on prognostic realistic scenario (Figure 1). For example, if we compare the situation with neighboring Poland [21], where EU policy on revision of waste management approaches has 
been in place for several years, in 2016 there was formed $0.79 \mathrm{~kg} /$ person / day (15\% less than in Ukraine the same year). In the long term and far term forecast, we have respectively 0.90 (an increase compared to 2016, 14\% - 12\% lower than in Ukraine) and $1.01 \mathrm{~kg} /$ person / day (gain 28\%, 33\% lower). In general, if the further development of waste management will be in line with today's trends, then in 2050, the generation of waste per capita in Ukraine will exceed one and a half times the same indicator for Poland. However, following an optimistic low carbon scenario [22], Ukraine has a chance in the future to significantly reduce the level of environmental pollution caused by the formation and placement of waste (Figure 1). At the same time, it will not be possible to prevent the growth of emissions in the area of transport.

Tragic facts about the death of people at the landfill near Lviv, concerning the "travel" of garbage in garbage dumps through the territory of the country, the terrible state of landfills and the absence of incinerators and waste processing plants, etc. indicate the need to attract additional management factors, primarily related to the new approach to transportation and logistics management in the field of waste management.

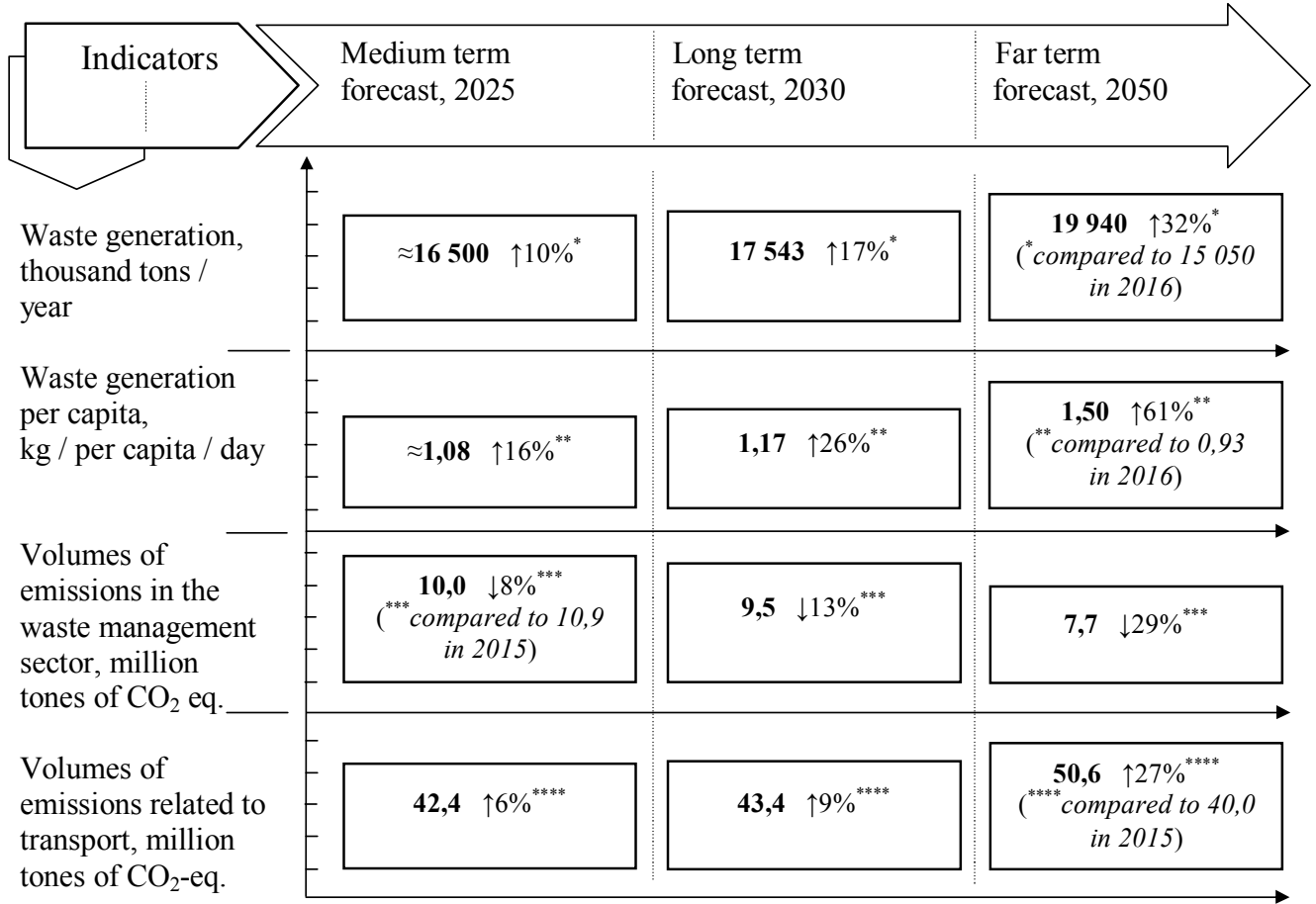

Fig. 1. Projection of waste generation (realistic scenario) and emissions in the sectors of waste Source: based on $[21 ; 22]$. and transport (low-carbon scenario) in Ukraine, by 2050

Reverse logistics (i.e. logistics, transport and related financial and information support: in the broad sense - waste management processes; in the narrow - waste streams) is a means of achieving positive environmental performance while also positive economic performance. In [14], a methodology is used to ensure the adoption of effective managerial decisions on the choice of methods for collecting, sorting and recycling plastic waste on the example of the Netherlands. The essence of the methodology is to optimize the design of the reverse logistics network, which should be understood as the implementation of such interrelated tasks: achieving a certain level of environmental and economic efficiency, ensuring the sustainability of the network, taking into account the interests of all stakeholders (households, municipalities, business representatives, etc.). The simplicity of the approach is explained by the usual consideration of alternatives to sorting plastics, ranging from on-site collection, i.e. households and industrial facilities, and passing the stage of additional sorting at so-called waste disposal centers to specialized plastic processing sites. The complexity of the approach is to use methods of economics and mathematical programming, namely: scenario analysis of (the 
baseline scenario is the current situation, alternative scenarios are set depending on the set of development strategies for the current situation), mixed integer linear programming, as well as graphical modeling of IBM LogicNet Plus 7.1. With these methods, it is possible to minimize both the cost of transportation of waste and its impact on the natural environment. Specifically, the test results showed that in some scenarios, a separate channel for collecting PET bottles are economically beneficial and reduces carbon emissions (up to $25 \%$ compared with existing municipal networks) [14].

Similarly, the [16] suggests the existence of a "symbiotic effect between waste recycling systems (HWRS) and domestic processing in discourse of reverse logistics (RL)".

In the [15], it is emphasized that one of the most important problems for the normal functioning of solid household waste management systems is the high costs of their collection and transportation. Therefore, it is logical to resolve this problem first, and the way to fix it is not less logical - "reduction" of the waste collection and transportation strategy, which should be understood literally: reduction of the way of transportation of waste from the place of their occurrence - to their place or return to production or utilization. By way of a heuristic solution to this problem and modeling the waste management situation, scientists have proven that the proposed transport and logistic scheme is able to reduce the total length of the way of waste collection by $30 \%$.

The authors of the [18] also point out that it is the collection and sorting of solid waste and the associated transportation costs require permanent funding. At the same time, it is first necessary to optimize the location of containers for waste collection (in the research, such a transport problem was solved on the example of the city of Dhankhad in India), using ArcGIS network analytics instruments that take into account the following parameters: the location of containers for waste collection, the network of roads, the distance between objects, population density, timetables for waste garbage trucks, their carrying capacity, transportation time, etc.

In the research [20], waste management processes are considered within the framework of the sustainability of municipal policy in
Sicily, in particular, in Palermo and the socalled concept of the ecological footprint EF. According to the new standards, domestic waste should pass the entire cycle from reprocessing to reuse, but in some cities in the region, by inertia, waste is disposed of at landfills. The role of transport logistics built into the modernized city policy is particularly important. The EF method was used both in building integrated waste management plans and in relation to individual waste management processes.

Taking into account the above, we consider the solution of the problem of managing transport-logistic processes of responsible waste management primarily in two aspects (Figure 2):

\section{Integration of the transport-logistics} system into the waste management system at the territorial level. Problem issues inherent to the waste management system automatically go to the level of its subsystems and interact with systems of other industries. (In a certain sense, it is a clustered approach, in which the importance of inter-branch relations is not less than the intra-branch connections). Therefore, the role of goal-setting and coordinating functions (understanding coordination as a function of establishing links between other management functions) in the field of waste management is increasing. The main objective is to increase the ecological and economic efficiency of processes related to the production, consumption and management of household and industrial waste. Using this principle, integration of transport and logistics operations into the waste management system should take place.

Among the main elements of this system, we are primarily interested in the management functions and related environmental-economic instruments (ecological taxation, environmental insurance, international and national standardization, in particular, ISO 13030 waste, ISO $14000 \quad-\quad$ environmental management, etc.) for managing transport and logistics processes of waste management. Along with the goal setting, the management functions are: planning, including the formation of a waste management strategy and its transport and logistics component; regulation of transportlogistics activities in the waste market; control and monitoring, covering the first 
environmentally unsafe transportation and disposal of hazardous waste, etc; motivation is a function of positive incentives, encouragement of economic entities and specialized organizations involved in the transportation, sorting and utilization of waste, to the implementation of environmentally safe, socially responsible and, at the same time, costeffective measures (in spite of, at first glance, unpredictable conflicts between economic and natural and ecological factors [23; 25]). According to these functions, we proposed a set of tasks outlined in the [24].

Optimum involvement of elements of different industries depends primarily on the level of responsibility and its concentration within a governing body; a situational possibility of applying the concept of joint liability, that is bringing to the problem of waste different ministries related to environmental protection, resource and energy policy, transport infrastructure and so on. Taking into account the environmental specificity of waste and the activities associated with them as an object of control, the relevant governing body should be the relevant ministry. At the same time, environmental policy at the state, regional and local levels should be transparent and provide ample opportunities for public monitoring and specialized monitoring, especially for the collection, transportation, storage and disposal of hazardous waste.

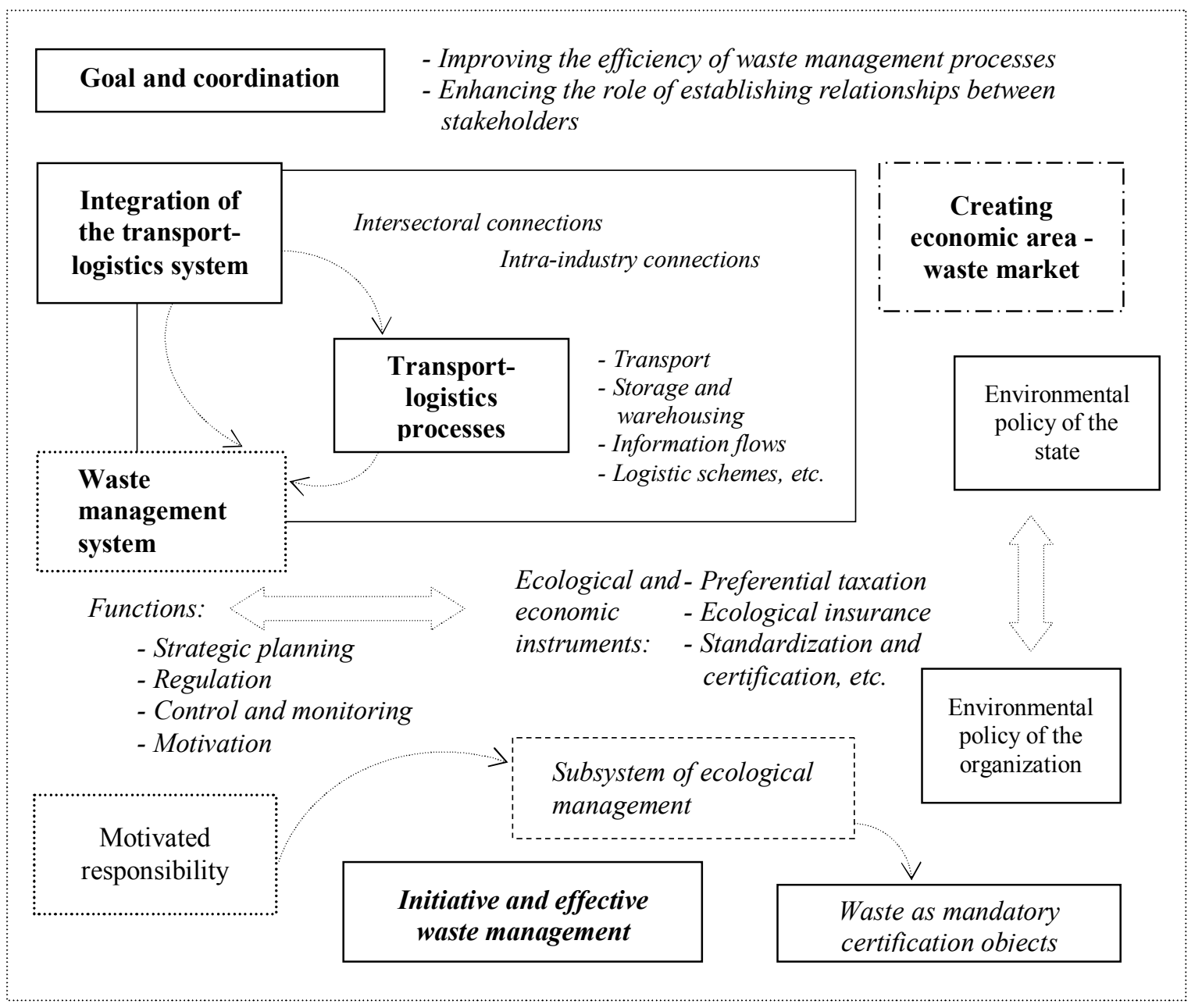

Fig. 2. Conceptual scheme of management of transport-logistics processes in the waste management system

Source: developed by the author.

2. Creating economic space for mutually resolving issues relating to transportation and other logistics operations of waste. Essentially, it is about a regulated waste market.
If the first aspect (concerning the integration of the transport and logistics system) more reflects the organizational aspects of waste management, then the second is aimed at using the economic potential of the industry. 
Market space will create competitive conditions for those economic entities that will be the first in the industry to initiate responsible waste management. In world practice, the system of standards ISO 14000 [26] has become the most widespread, and it establishes clear principles and rules for the implementation of environmental management, aimed at implementing the corresponding policy at the organization level.

The subsystem of environmental management within the framework of the waste management system, in particular its transport and logistics component, has, firstly, to formulate an environmental policy that at the micro-level will be adequate to the macro-ecopolitics as a consequence of the creation of an economic space in the field of waste management; and secondly, it has to become an effective instrument for realizing the concept of motivated responsibility. It is about an initiative and effective waste management based on environmentally-oriented transport and logistics actions.

Conclusion. As a result of the research, we can state that in the field of waste management one of the priorities is the task of increasing the role of transport logistics. Under the optimistic low carbon scenario, Ukraine in the long run can significantly reduce the level of environmental pollution caused by the formation and disposal of waste, but it will still increase emissions in the transport sector. Reverse logistics as material-technical, transport and related financial and informational support for waste management processes is considered as a means to achieve positive ecological and economic efficiency. Solving the problem of managing transport-logistics processes of responsible waste management is seen in two aspects: integration of the transport-logistics system into the waste management system at the territorial level; creating an economic space for mutually agreed solutions to issues of transportation and other logistic waste operations. Such a conceptual approach will allow to create competitive conditions for the subjects of ecological and economic activity, which initiate the responsible management of waste in aspects of their transportation, sorting, utilization, etc. according to the standards ISO (ISO 13030, ISO 14000). Further research will be aimed at forming a system of environmental and economic indicators of motivated transport and logistics activities in the field of waste management.

\section{REFERENCES}

1. Burkinsky, B. V., Martyenko, A. I., \& Khumarova, N. I. (2016). Institutional aspects of administration of the sphere of natural resources use in Ukraine. Economy of Ukraine, 1, 72-83 [in Ukrainian].

2. Khumarova, N. I. (2015). Administration of the sphere of natural resources: problems and ways of their solution. Economical Innovations, 2(60), 241-249 [in Ukrainian].

3. Martienko, A., \& Khumarova, N. (2017). Improvement of the administration system in the field of natural resources use. Economics. Ecology. Socium, 1(1), 71-81.

4. Petrushenko, M. M., \& Shevchenko, H. M. (2013). Management of ecological-economic conflicts in the context of the optimal mechanisms theory for the resources allocation. Actual problems of economy, 3, 186-192 in Ukrainian].

5. Khumarova, N. I. (2008). Ecologization of innovative strategies to reduce waste production. Bulletin of Economic Science of Ukraine, 2, 155-160 [in Russian].

6. Petrushenko, M. M., \& Shevchenko H. M. (2018). Regulation of ecologic-and-economical risks and the responsibility for human well-being: for example of waste management. Economic Innovations, 3(68), 165-175.

7. Boychenko, S. V., Leyda, K. \& Ivanchenko, O. V. (2016). Ecology, utilization and recycling of vehicles: trends and prospects of development. Knowledge-based technologies, 2, 221227 [in Ukrainian].

8. Voronina, R. (2008). Recycling logistics. Bulletin of Lviv Polytechnic National University, 23(623), 28-33 [in Ukrainian]. 
9. Vostryakova, V. I. (2014). "Green" logistics of the agrarian sector as a component of the ecological, energy and food security of the state. Collection of scientific works of VNAU. Series: Economic Sciences, 2, 145-152 [in Ukrainian].

10. Hurch, L. M., \& Khmara, L. Ye. (2014). Development of "green logistics" in Ukraine. Bulletin of the National University "Lviv Polytechnic". Logistics, 811, 86-91 [in Ukrainian].

11. Dzyad, O. V., \& Zvyetayeva, K. V. (2015). Recycling of municipal waste in industrialized countries: a comparative aspect. Bulletin of Dnipropetrovsk University. Series: World Economy and International Economic Relations, 23(7), 3-12 [in Ukrainian]. doi:10.15421/181501.

12. Zayets, V. V. (2013). Transportation of radioactive waste to the field of the complex "Vector" and PZRO "Buryakovka". East European Journal of Advanced Technology, 1/6, 31-34 [in Russian].

13. Popovych, N. P., Malovanyy, M. S., \& Popovych, V. V. (2018). Effectiveness of specialised equipment operation for transportation of hazardous waste in the composition of household materials. Scientific Bulletin of UNFU, 28(3), 111-116[in Ukrainian]. doi:10.15421/40280323.

14. Bing, X., Bloemhof-Ruwaard, J. M. \& van der Vorst, J. G. A. J. (2014). Sustainable reverse logistics network design for household plastic waste. Flexible Services and Manufacturing Journal, 26, 119. 119. doi:10.1007/s10696-012-9149-0.

15. Das, S., \& Bhattacharyya, B. K. (2015). Optimization of municipal solid waste collection and transportation routes. Waste Management, 43, 9-18. doi:10.1016/j.wasman.2015.06.033.

16. Jalil, E. E. A., Grant, D. B., Nicholson, J. D. \& Deutz, P. (2016). Reverse logistics in household recycling and waste systems: a symbiosis perspective. Supply Chain Management: An International Journal, 21(2), 245-258. doi:10.1108/SCM-02-2015-0056.

17. Joshi, R., \& Ahmed, S. (2016). Status and challenges of municipal solid waste management in India: A review. Cogent Environmental Science, 2, 1-18. doi:10.1080/23311843.2016.1139434.

18. Khan, D., \& Samadder, S. R. (2016). Allocation of solid waste collection bins and route optimization using geographical information system: A case study of Dhanbad City, India, Waste Management \& Research, 34(7). doi:10.1177/0734242X16649679.

19.Marczak, H. (2016). Logistics of waste management in healthcare institutions. Journal of Ecological Engineering, 17(3), 113-118. doi:10.12911/22998993/63319.

20. Peri, G., Ferrante, P., La Gennusa, M., Pianello, C., \& Rizzo, G. (2018). Greening MSW management systems by saving footprint: The contribution of the waste transportation. Journal of Environmental Management, 219(1), 74-83. doi:10.1016/j.jenvman.2018.04.098.

21. World Bank (2018). What a waste 2.0: A global snapshot of solid waste management to 2050 Datatopics. Retrieved from: http://datatopics.worldbank.org/what-a-waste/.

22. UNDP in Ukraine (2013). Prediction of GHG emissions in Ukraine: paths by 2050. Thomson Reuters Carbon Report / UNDP in Ukraine. 41. Retrieved from: http://www.ua.undp.org.

23. Petrushenko, M. M. (2012). Economic games against nature: a model for decision-making in the field of environmental conflict management. Business Inform, 4, 130-132 [in Ukrainian].

24. Kodzhebash, A., \& Krivencev, A. (2018). Transport and logistic components of waste management strategies in the context of implementing resource-saving and environmental policy. Economics. Ecology. Socium, 2(4), 91-102.

25. Koval, V., Petrashevska, A., Popova, O., Mikhno, I., \& Gaska, K. (2019). Methodology of ecodiagnostics on the example of rural areas. Architecture Civil Engineering Environment, 12(1), 139-144. doi: 10.21307/ACEE-2019-013

26. International Organization for Standardization ISO (2018). ISO $13030 / 14000$. Retrieved from: https://www.iso.org/standards.html. 